\title{
„Warszawa jest przecież tęczowa”. Obraz przestrzeni miasta w autodziecięcych tekstach kultury nagrodzonych w konkursie varsavianistycznym Muzeum Warszawy'
}

\section{Abstrakt:}

Przeprowadzona w artykule analiza prac nadesłanych przez uczniów szkół podstawowych i średnich na konkurs literacki organizowany przez Muzeum Warszawy dowodzi, że dziecięcy autorzy powielają schematyczne, obecne w przewodnikach $\mathrm{i}$ internecie ujęcia przestrzeni miasta, omijają zaś to, co w tej przestrzeni jest zorientowane na młodych i najmłodszych mieszkańców i turystów. Wynika to z jednej strony z faktu, że sami warszawiacy nie mają wiedzy o miejscach atrakcyjnych dla dzieci, z drugiej - z chęci dostosowania przez dziecięcych autorów ich prac do hipotetycznych oczekiwań dorosłych jurorów. Ten drugi powód skutkuje również przeładowaniem faktografią, szczegółami historycznymi i topograficznymi. Dziecięcy twórcy nie czerpią inspiracji ze skierowanej do nich współczesnej literatury, z twórczości pisarzy, którzy chcą dorosnąć, ale nie do bycia nauczycielem czytających, lecz do bycia dzieckiem.

Słowa kluczowe:

dzieciństwo, konkurs varsavianistyczny, Muzeum Warszawy, twórczość własna dzieci i młodzieży, Warszawa

* Grzegorz Leszczyński - prof. dr hab., pracuje na Wydziale Polonistyki Uniwersytetu Warszawskiego (jako kierownik Zakładu Literatury Popularnej, Dziecięcej i Młodzieżowej w Instytucie Literatury Polskiej oraz dyrektor Centrum Języka Polskiego i Kultury Polskiej dla Cudzoziemców Polonicum). Jego zainteresowania badawcze obejmują literaturę dla dzieci i młodzieży oraz literaturę drugiej połowy XIX wieku. Kontakt: gmleszcz@uw.edu.pl.

1 Artykuł powstał na podstawie referatu wygłoszonego podczas XXIX Sesji Varsavianistycznej Warszawa w kulturze dla dzieci i młodzieży, sfinansowanego ze środków Biblioteki Publicznej m.st. Warszawy - Biblioteki Głównej Województwa Mazowieckiego 


\section{"Warsaw is rainbow-coloured after all": The Image of the City Space in Auto-Children's Cultural Texts Awarded in the Museum of Warsaw's Writing Competition}

\section{Abstract:}

The analysis of works submitted by elementary and secondary school students to the writing competition organised by the Museum of Warsaw shows that child authors reproduce schematic depictions of the city space, present in guidebooks and on the internet, while avoiding everything that is oriented towards its young and youngest inhabitants and tourists. This results, on the one hand, from the fact that Warsaw inhabitants themselves have no knowledge of places attractive to children and, on the other, from the desire of child authors to adjust their works to the hypothetical expectations of the adult jury. This second reason also results in an overload of facts as well as historical and topographical details. Child authors are not inspired by contemporary literature directed at them, by writers who want to grow up not to be their readers' teachers, but to be children.

\section{Key words:}

childhood, Warsaw writing competition, Museum of Warsaw, literature written by children and young adults, Warsaw

K im jest dziecko jako wpisany w teksty autor prac autodziecięcych, przesyłanych na konkursy literackie? Kto kryje się za utworami prozatorskimi, poetyckimi, za opowiadaniami, scenkami z życia codziennego, za obrazkami z przeszłości i miniaturami refleksyjnymi? Jak postrzega swoje miasto, swoją „małą ojczyznę”, swoją - jak pisał Jerzy Cieślikowski (1974) „okolicę dzieciństwa”? W jaki sposób kreuje przestrzeń miasta? Co w niej dostrzega, co pomija? Przede wszystkim: na ile ów autodziecięcy podmiot czynności twórczych (Okopień-Sławińska, 1987) stanowi kreację, poddaną procesowi adultyzacji ${ }^{2}$, na ile zaś zachowuje autentyzm dziecięcości, wyrażający się w eksponowaniu właściwych dziecku emocji, zainteresowań, fascynacji, poglądów, perspektywy postrzegania obiektów i zjawisk? Poszukiwanie odpowiedzi na te pytania jest realizacją postulatu Macieja Wróblewskiego (2018), wskazującego na konieczność podjęcia kulturoznawczych badań obej-

2 Jak piszą Aneta Jarzębińska i Barbara Chojnacka (2018), „adultyzacja to swoiste skłanianie dziecka do przejścia ku dorosłości, szybkiego uzyskania autonomii i samodzielności [...]. Ta swoista transmisja międzypokoleniowa dokonuje się przy współudziale środowiska biologicznego i społecznego, a dotyczy także cech psychofizycznych, pełniących funkcję czynników sprzyjających odwróceniu ról [dziecka i dorosłego]” (s. 167). 
mujących stworzone przez autorów dziecięcych „wszelkiego rodzaju teksty pisane (literackie, użytkowe, dokumentalne), wytwory ikoniczne (obrazy, fotografie, filmy) i zapisy audialne o dokumentacyjnym charakterze, których autorem jest dziecko”; jak dowodzi Wróblewski, „powinien interesować badacza ich aspekt źródłowy”, rozumiany „jako zapis doświadczeń dziecka. Tego typu materiał można nazwać autodziecięcymi tekstami kulturowymi. Rzecz w tym, by uwypuklić w nich nie tyle »literackość«, "historyczność«, »folklorystyczność«, ile właśnie skierować uwagę na samego autora, a więc dziecko" (s. 53).

Przedmiotem prowadzonej $\mathrm{w}$ niniejszym szkicu analizy są dziecięce prace literackie nagrodzone $\mathrm{w}$ pierwszych czterech edycjach konkursu varsavianistycznego, organizowanego od 2016 roku. Celem corocznych konkursów, wedle organizatora, Muzeum Warszawy (2020), jest „popularyzowanie wiedzy o Warszawie”, „poszerzenie znajomości historii Warszawy”, „pogłębienie zainteresowań varsavianistycznych”, „promowanie i rozwijanie uzdolnień literackich”, „zachęcenie do korzystania z księgozbioru Biblioteki Muzeum Warszawy" (s. [1]). Aby cele te zostały osiągnięte, uczestnicy, a są nimi uczniowie starszych klas szkół podstawowych (obecnie IV-VIII; wcześniej byli to uczniowie gimnazjum) i ponadpodstawowych, muszą, zgodnie ze wskazówkami zawartymi w regulaminie, zdobyć wiedzę na wskazany przez organizatorów, zmieniający się z każdym rokiem temat, obejrzeć wybrane wystawy (szczególnie czasowe lub okolicznościowe) prezentowane w Muzeum Warszawy (do tematyki wystaw nawiązują hasła kolejnych edycji konkursu), znaleźć i wykorzystać stosowne informacje itd. Dydaktyczna i wychowawcza wartość tego rodzaju przedsięwzięć polega na budzeniu zanikającego w postawach młodego pokolenia patriotyzmu lokalnego, który ma fundamenty zarówno w sferze uczuć, wyrażających się w odczuwaniu więzi emocjonalnej z przestrzenią, jak i w poczuciu odpowiedzialności za „okolice dzieciństwa", za zamieszkujących je ludzi, za trwanie dziedzictwa kulturalnego i historycznego, a to bez fundamentu wiedzy, bez poczucia zakorzenienia - nie jest możliwe.

Prace dzieci i młodszych nastolatków mogą jednak być też nieocenionym źródłem wiedzy na temat tego, jak to pokolenie postrzega własną małą ojczyznę - miejsce, w którym się wychowuje, rozwija, zdobywa doświadczenia, jak widzi swoje miasto, co w przestrzeni rodzinnego miasta zaciekawia, przyciąga uwagę i rozbudza wyobraźnię, a jednocześnie - co w obserwacjach przestrzeni miejskiej pomija, co w horyzoncie rozpoznań, spostrzeżeń i zainteresowań z różnych względów nie istnieje. Przedmiotem rozważań są w niniejszym artykule, jak zostało już wspomniane, prace nagrodzone w czterech edycjach konkursu 
varsavianistycznego (2016-2019)33, ale wnioski, które z analizy wypływają, znalazłyby zapewne odzwierciedlenie w utworach dziecięcych przesyłanych na inne tematyczne konkursy literackie, organizowane w całym kraju ${ }^{4}$. Konkurs Muzeum Warszawy odbywa się corocznie, za każdym razem towarzyszy mu inne hasło tematyczne. W 2016 roku brzmiało ono Warszawa w Twojej legendzie, w 2017 - Spacer nad Wisłe, w 2018 - Rzecz o rzeczach warszawskich, wreszcie w 2019 - Warszawa i Syrena. Syrena i Warszawa. Precyzowanie zakresów tematycznych ma na celu uniknięcie powtórzeń, schematyzmu i monotonii prac, pozwala na precyzowanie wypowiedzi, inspiruje zainteresowania, zmusza do zdobywania wiedzy i szukania ciekawostek. Niezależnie od zmienności haseł, tematów i obszarów inspiracji, w literackich wypowiedziach dzieci powracają motywy pozwalające zrekonstruować ich wizję przestrzeni miasta.

Najczęściej powtarzającym się motywem jest charakterystyczna dla większości wypowiedzi pora roku - późna wiosna lub lato. Warszawa tonie w kwiatach, pełno ich w parkach, na trawnikach biegnących wzdłuż ulic i chodników, w kawiarnianych ogródkach. W mieście, co charakterystyczne, nie ma upału - od strony Wisły wieje lekki, przyjazny, chłodzący wiatr. Na ulicach gwarno - ludzie niespiesznym krokiem spacerują, rozmawiają, przesiadują w kawiarenkach lub w przykawiarenkowych ogródkach. Obraz ten malowany jest słońcem, radosny, pogodny i ciepły. Najpewniej są wakacje, może majowa bądź czerwcowa sobota czy niedziela - wszyscy mają dużo czasu, nigdzie nie widać, by ktoś się spieszył, kogoś popychał, przeciskał się przez tłum. Gwarowi towarzyszy tzw. biały szum, raczej uspokajający niż męczący - samochody nie wydają żadnych dźwięków, nikt nie trąbi, nikt nie mówi podniesionym głosem, nie słychać płaczu dzieci czy czyichś nawoływań. To sielanka, żywcem przeniesiona ze „wsi spokojnej, wsi wesołej” do równie spokojnego i równie radosnego miasta - współczesnego raju.

Inne pory roku sytuują się niemal poza horyzontem dziecięcego zainteresowania. Prawdą jest, że kolejne edycje konkursu są ogłaszane wiosną, a autorzy mogą prace nadsyłać do września, ale ta okoliczność jedynie częściowo tłumaczy dominację wiosny i lata w warszawskich obrazach, obrazkach

3 Wszystkie przywoływane w artykule teksty znajdują się w archiwum Muzeum Warszawy i zostały udostępnione autorowi do celów badawczych. Prace konkursowe laureatów pierwszych miejsc kolejnych edycji dostępne na stronie organizatora: https://muzeumwarszawy. pl/konkurs-literacki-muzeum-warszawy/ (pobrane 8 kwietnia 2021). W artykule wszystkie teksty konkursowe są cytowane w zapisie oryginalnym.

4 Twórczość literacka dzieci była przedmiotem licznych analiz prowadzonych z perspektywy pedagogicznej, edukacyjnej i literaturoznawczej (np. Gloton, Clero, 1971/1976; Kujawiński, 1990; Kruze-Sikorska, 2006; Popek, 1988; Semenowicz, 1973; Uszyńska-Jamrot, 2007; Zborowski, 1986). 
i scenkach rodzajowych. Dziecięca wyobraźnia nie sięga poza czas kanikuły, weekendu czy wakacji w mieście, czas miejskiej „majówki”. Rzecz jednak nie tyle w swobodnych dziecięcych wyborach, ile w kliszach, które młodym autorkom i autorom podsuwa kultura popularna: jesień implikuje nastroje melancholijne, wiosna - witalne; jesień przynosi skojarzenia z przemijaniem, starością i śmiercią, wiosna przeciwnie - z młodością i siłami życiowymi. Są to schematy ukształtowane jeszcze przez konwencję sielankową, w której cywilizacja przeciwstawiona była naturze - źródłu radości i poczucia szczęścia. W wypowiedziach autodziecięcych Warszawa ujmowana jest tak, jakby nie była miejscem cywilizacji, lecz królestwem natury, jakby słońce, wiatr i przecinająca je rzeka neutralizowały urbanizm. Z oświeceniowego przeciwstawienia natury i kultury, formułowanego w pismach Davida Hume'a i Jeana-Jacques'a Rousseau, dziecięcy twórcy mimowolnie i nieświadomie czerpią pełnymi garściami, ukazując miejski świat zgodnie ze schematem, w myśl którego szczęśliwy może być tylko człowiek żyjący w świecie natury i poprzestający na małym. Wyobraźnia dzieci poddana jest presji kulturowych klisz, które podpowiadają, że piękna jest słoneczna wiosna, a brzydka - słotna jesień, że lato kojarzy się z wakacjami, a wakacje i Warszawa to przecież „lato w mieście”. Uczestnicy konkursu mogliby powtórzyć za jednym z literatów zgromadzonych w Salonie Warszawskim w Dziadach. Części III Adama Mickiewicza (1832): „Sławianie, my lubim sielanki” (s. 137). Sielanka XVIII-wieczna ceni dojrzałe lato i wiosnę, oddala zaś „złe” pory roku: jesień i zimę. Oddziałuje na dziecięcych twórców ten schemat, obecny we współczesnej kulturze popularnej, rodowodem sięgający poetyckich obrazów Arkadii - wyidealizowanej krainy wiecznej wiosny, spokoju i szczęścia, zamieszkiwanej przez ludzi wolnych od trosk i niedostatku.

Z dominacji schematów kultury popularnej wynika nieobecność motywów związanych $\mathrm{z}$ innymi porami roku. W miejskim pejzażu arkadyjskiej Warszawy trudno znaleźć obrazy bożonarodzeniowych girland, rozświetlających mroczniejące arterie, chodniki, ulice, place, parki i zamieniających je w wieczny ogród radości i światła. Nie ma charakterystycznej dla miasta wysokiej, wielobarwnej świątecznej choinki, nie ma barwnych iluminacji wzdłuż Traktu Królewskiego, spowijających go iście baśniową aurą, nie ma rozstawionych wzdłuż Krakowskiego Przedmieścia i Nowego Światu, a nawet dalej, w okolicach Łazienek, baśniowo roziskrzonych, pokrytych setkami różnokolorowych światełek powozów zaprzężonych przez zachwycające renifery, nie ma wykonanych z kolorowych lampek imitacji starych autobusów, nie ma magicznych bram, przez które można przechodzić niczym przez wrota Sezamu, zabawnych monstrualnością bombek, wielkich paczek przewiązanych kolorowymi świecącymi kokardami... Nie ma wszystkich tych przyciągających 
uwagę i dzieci, i dorosłych obiektów rozciągniętych od kolumny Zygmunta do Łazienek, do których tłumnie przychodzą warszawiacy i przyjezdni, poddając się atmosferze świąt i urokowi iluminacji. Nie ma wzmianki o fantazyjnie ozdobionych witrynach sklepowych i frontonach kamienic, o wykonanych z kolorowych lampek aniołach, obłokach, o drzewach, których konary skrzą się elektrycznymi soplami i migającymi gwiazdkami, o girlandach świetlnych rozciągniętych wzdłuż i w poprzek niezliczonych warszawskich ulic i kamienic. Nie ma przedświątecznej krzątaniny, atmosfery świąt, radości miasta żyjącego w niezwykły i olśniewający dzieci sposób... Świętego Mikołaja wędrującego po ulicach, sklepach i jarmarkach - też nie ma. Zresztą i samych świątecznych jarmarków zabrakło. A przecież iluminacje świąteczne zamieniają pogrążone w późnojesiennych mrokach miasto $\mathrm{w}$ istną baśń, w baśniowy ogród, niemal jak na obrazie Bajka zimowa Ferdynanda Ruszczyca (1904), na którym spotykają się przeciwległe światy: czarnej nicości i srebrnej, tajemniczej zimy.

Nie ma również Warszawy jesienią, pokrytych kolorowymi liśćmi ogrodów - Botanicznego, Saskiego, Krasińskich, Wilanowa, Łazienek... Ta lista nieobecności dziwi równie silnie jak poprzednia, związana z zimą. Łazienki są popularnym miejscem rodzinnych spacerów, każdego dnia, szczególnie w weekendy, widać tam tłumy dzieci zbierających kasztany i układających liście w wielobarwne bukiety. Od października w Wilanowie można odwiedzać Królewski Ogród Światła i oglądać multimedialne mappingi na fasadzie pałacu. I o tym milczą autorzy prac konkursowych. Jeśli w ogóle na horyzoncie dziecięcych czy wczesnomłodzieńczych skojarzeń pojawia się jesienne miasto, to ta pora roku jest wspomniana lakonicznie, jakby od niechcenia. Charakterystyczny przykład z nagrodzonej w I edycji konkursu pracy uczennicy I klasy gimnazjum:

Fryderyk [Chopin] wącha kwiaty, wsłuchuje się w ciszę, jaka panuje wokoło i rozkoszuje się pięknem Warszawy. W lecie podziwia kaczki pływające po tafli wody. Często kładzie się na trawie, patrzy w gwiazdy i obserwuje księżyc błyszczący w oddali. Jesienią podziwia kolory liści i zbiera kasztany. W zimie urządza bitwy na śnieżki, wspominając swoje lata dzieciństwa (Autorka 1, 2016).

Podobnie w nagrodzonym w II edycji wierszu nieco starszej autorki z drugiej klasy liceum ogólnokształcącego:

\footnotetext{
Zima w Warszawie

Gdy ciepło cicho śpią ślimaki

czarne ogniki błyszczą w skałach

mgła układając szron w zygzaki
} 
przymrozkiem wciska się do ciała

Gdy światło pełni płynie rzeką

nurkują czarne kormorany

chcąc srebrnym oknem wejść daleko

w świat na ich skrzydłach zapisany

Gdy głos tramwajów kołysanek

po wszystkich mostach się rozbiega

czekając w półśnie na poranek

faluje miasto na dwóch brzegach (Autorka 2, 2017).

Jeśli w warszawskich obrazach czy scenkach rodzajowych pojawia się zima, to podobnie jak jesień - zniechęcająca, niemiła, deszczowa, taka, która nie sprzyja ani zabawom, ani spacerom, ani wyobraźni, bo nie ma sobie nic z magii, ciszy, bajecznego pejzażu i przedświątecznego czy świątecznego nastroju.

Jesień i zima to pory roku nieobecne w kulturowych kliszach i pocztówkowych pejzażach, wskazujących na obrazy arkadyjskie jako ojczyznę szczęścia. Wiosna, w przeciwieństwie do następujących później dwóch „gnuśnych" pór roku, wydobywa kolory, a - jak dowodzi wiersz przywołany w tytule niniejszego szkicu - „Warszawa jest przecież tęczowa”. Autorka cytowanego utworu to uczennica piątej klasy szkoły podstawowej; wiersz został nagrodzony (II miejsce) w konkursie w 2019 roku. Jest bardzo charakterystyczny, niczym w soczewce zbiegają się w nim bowiem powracające w innych dziecięcych tekstach kojarzące się z wiosną motywy, nastrój radości, spokoju, beztroski. Miasto jest wielobarwne, budzi skojarzenia z wieczną zabawą i ogrodem rozkoszy:

Warszawa jest zielona jak wiosną Ogród Saski, Gdzie słońce w fontannie odbija swe blaski.

Warszawa jest fioletowa jak krokusów dywan,

Rosnących w parku, w którym często bywam.

Warszawa jest żółta jak słońce, co nad nią świeci,

A wtedy na skwerku bawią się dzieci.

Warszawa jak jej mieszkańcy jest przecież tęczowa,

I jak paleta malarza kolorowa (Autorka 3, 2019).

Bogactwo kolorów jest charakterystycznym motywem przestrzeni Warszawy. Miasto przypomina tęczę. Zapewne skojarzenie to było nieprzypadkowe. Olśniewające pięknem kolorów przywodzi na myśl wielobarwny łuk rozpięty na niebie, ale obecność motywu tęczy na horyzoncie dziecięcych skojarzeń mogła wynikać nie tylko ze skojarzenia malarskiego, owocującego zgrabną metaforą, lecz także z impulsów związanych z medialnymi i środowiskowymi dyskusjami nad szeregiem wydarzeń sprowokowanych instalacją artystyczną 
Julity Wójcik - słynną tęczą, prezentowaną w latach 2011-2012 przed budynkiem Parlamentu Europejskiego, a w 2012 roku ustawioną na warszawskim placu Zbawiciela. Instalacja była wielokrotnie podpalana przez niezidentyfikowanych sprawców, środowiska wrogo nastawione do osób nieheteronormatywnych postrzegały w niej znak ,ideologii LGBT”. Dyskusje wokół instalacji, mimo jej zdemontowania w 2015 roku, trwały przez kolejne lata, a „problem tęczy" powracał $\mathrm{w}$ dyskursie medialnym m.in. za sprawą upowszechnienia przez internet w 2018 roku pracy Elżbiety Podleśnej, przedstawiającej Matkę Boską Częstochowską z tęczową aureolą. Wizerunek zainspirował serię dzieł i wydarzeń o charakterze artystycznym lub pseudoartystycznym, które ożywiły dyskusję wokół symboliki tęczy ${ }^{5}$. W 2018, a więc w roku, w którym wiersz został nadesłany na konkurs, Gazeta Wyborcza donosiła: „Tej tęczy nie da się podpalić. Powróciła jako obraz wyświetlony na wodnej mgiełce. To i tak wystarczyło, by w polskiej polityce znów się zagotowało. W piątek tęcza wróciła na pl. Zbawiciela. Jest nie do podpalenia: w formie projekcji na wodnej mgiełce" (Karpieszuk, Wojtczuk, 2018).

Nie dziwi zatem, że dziecko osnuło wiersz wokół motywu tematycznego, o którym było wówczas głośno, i to od dłuższego czasu. Zapewne nie rozumiało istoty zaciekłych sporów ideologicznych i - jeśli je poznało - nagłaśnianych medialnie słów Roberta Winnickiego z Ruchu Narodowego: „Spłonął symbol zarazy. Ten symbol to wielkie zagrożenia dla Polski, to symbol rewolucji lewackiej” (wkk, 2013). „Symbol zarazy”, „rewolucja lewacka” - to nie są wyrażenia zrozumiałe dla jedenastolatki. Nie ulega jednak wątpliwości, że sama tęcza jako obraz, temat czy motyw przewijający się w dyskursie medialnym i domowych rozmowach, w konsekwencji nawet rówieśniczych wymianach zdań, mogła oddziaływać na wyobraźnię dziecięcej autorki.

Podsumowując tę część rozpoznań, należy stwierdzić, że dziecięcy twórcy powielają stereotypy narzucone przez kulturę dorosłych. Niekiedy trudno oprzeć się wrażeniu, że to właśnie dorosły jako wzorzec swoistej „poprawności” prac jest może nie cenzorem, ale punktem odniesienia młodych twórców. To dorosły narzuca schematy i tworzy klisze, ocenia nadesłane utwory; to dorosły decyduje o tym, czyja praca znajdzie się w śmietniku zapomnienia, a czyja zostanie opromieniona laurem zwycięstwa. Sytuacja pisania przez dziecko pracy na konkurs, w którym role jurorów pełnią dorośli, jest pod wieloma względami podobna do sytuacji pisania szkolnego wypracowania na ocenę dorosły wyznacza temat, ramy czasowe, w których utwór ma zostać oddany do

5 Podsumowaniem tych dyskusji jest artykuł Dlaczego właściwie tęcza sprofanowała Matke Boską? autorstwa Katarzyny Kasi (2019). 
oceny, nagrody, jest zarówno punktem odniesienia procesu twórczego (jako hipotetyczny odbiorca tekstu), jak i punktem dojścia końcowej ewaluacji (jako sędzia, od wyroku którego nie można się odwołać). Pisana na konkurs praca jest zorientowana nie na ekspresję dziecięcych przeżyć, lecz na spełnienie domniemanych oczekiwań hipotetycznego dorosłego jurora, którego nie tyle rzeczywista postać, ile kulturowy konstrukt jest katalizatorem działań twórczych dziecka. Konstrukt ten utkany jest z różnorodnych elementów: doświadczeń szkolnych, wyobrażeń na temat postaci dorosłego pisarza i przebiegu procesu twórczego, powziętych na podstawie warunków konkursu domniemań na temat oczekiwań jurorów. Autorzy zatem świadomie lub mimowolnie odsuwają na plan dalszy własne dziecięce spostrzeżenia i przeżycia, własny dziecięcy świat, przyjmują zaś optykę „pożądanego” przez jurorów kształtu tekstu.

To dlatego wśród prac wyróżnionych w konkursie nie pojawiają się motywy i obrazy związane z miejscami i emocjami typowo dziecięcymi. Ani razu nie zostało wspomniane wesołe miasteczko, choć lunaparki goszczą corocznie w sezonie wiosenno-letnim w wielu miejscach Warszawy (w samym tylko 2019 roku było ich sześć: na Bemowie, na Stegnach, na Targówku, Saskiej Kępie, a nawet w samym centrum miasta: na placu Powstańców Warszawy). Nie ma cyrku, będącego właściwie reliktem przeszłości, ale zawsze przecież epatującego egzotyką przedstawień. Cyrk Zalewski corocznie daje przedstawienia w stolicy, poprzedzone kampanią plakatową. Nie ma wielu miejsc, które - jak można sądzić - są lub powinny być bliskie dzieciom: ogrodów jordanowskich, placów zabaw i boisk. Zrozumiałe jest, że brakuje opisu zabaw chodnikowych (zniknęły one z panoramy polskich miast przed kilkunastu laty), ale niewymienienie takich miejsc, jakie mogłyby fascynować dzieci, wskazuje albo na swoistą, silną i powszechną wśród małoletnich twórców autocenzurę, nakazującą własną dziecięcość traktować jako coś wstydliwego, niegodnego upublicznienia, swego rodzaju infantylną wylinkę, którą "doroślejący” czy raczej pozujący na „doroślejącego", ale czujący się „niedorosłym” pisarz - odrzuca. Byłoby więc to zjawisko przypominające lęk przed Gombrowiczowskim „upupieniem”, wtrąceniem w niedojrzałość, w dziecinność, z której wydobyć się można jedynie przywdziewając, jak powiedziałby Karol Irzykowski (1903), ,szatę, w której mogą już pokazać się światu, - w tzw. płaszczyk" (s. 191), chroniący przed ujawnieniem tego, co starannie, pieczołowicie skrywane w "podziemiach duszy”.

Stąd właśnie wynikają wybory miejsc, które dziecięcy autorzy uznają za ikoniczne dla Warszawy. Oto np. dzieci wskazują na charakterystyczny dla Warszawy Nowy Świat - ulicę, na której nie ma dla nich niemal żadnych atrakcji, są za to atrakcje dla dorosłych: sklepy z kosztownymi upominkami, najdroższe w Warszawie restauracje i kawiarnie. Dalej wymieniane są Stare 
Miasto i plac Zamkowy. Znowu - miejsca niedziecięce. Z budynków - Pałac Kultury i Nauki, Pawiak i Belweder. Same miejsca, które - może poza Pałacem Kultury z jego wysokościową panoramą miasta - nie kojarzą się $\mathrm{z}$ atrakcjami dla dzieci i nastolatków. Najpewniej to panujący w ostatnich latach nastrój niechęci do kleru spowodował całkowity brak budynków sakralnych, za to są... muzea. Wizyta w muzeach nie jest oczywista, dlatego wymaga uzasadnienia - a to złą pogodą, a to ciekawą wystawą, a to znowu propozycją ze strony dorosłych. Kilka przykładów, kolejno z prac dwóch uczennic IV klasy szkoły podstawowej i uczennicy klasy V:

Pewnej ciepłej soboty, razem z rodziną postanowiłam odwiedzić Muzeum Warszawy. Można zapytać: dlaczego akurat muzeum? Podczas, gdy moi koledzy i koleżanki zajadały popcorn w kinie, ja uczyłam się czegoś nowego. Właśnie $\mathrm{z}$ tego powodu moje wyniki z historii były wręcz świetne. Cała moja klasa była tym bardzo zdziwiona, ale dla mnie to nie miało znaczenia. W przeciwieństwie do niektórych dzieci nie zależało mi aby się pochwalić. Przeciwnie. Wolałam zachowywać takie informacje dla siebie. I zazwyczaj dobrze na tym wychodziłam (Autorka 4, 2018).

Wiktor - uczeń czwartej klasy jednej z warszawskich szkół na Żoliborzu, nie miał tego dnia żadnego pomysłu na ciekawe spędzenie popołudnia. Chmury zasnuwały niebo i padał deszcz, więc nie mógł pobiec na boisko, by pograć w piłkę z kolegami. Uparcie poszukiwał kolejnej gry w swoim nowym smartfonie. Wtem mamusia zawołała: „Słuchajcie, mam pomysł! Pojedziemy do Muzeum Warszawy". Tatuś uznał propozycję za nader ciekawą i wziąwszy z komody kluczyki, zbiegł do samochodu. Wiktor napominany przez mamusię, wciąż ociągając się, dołączył do rodziców. Nie mógł się domyślać, że czeka go jedna z najciekawszych podróży w jego życiu (Autorka 5, 2018).

Lubię stare rzeczy, dlatego zainteresowała mnie wystawa główna w Muzeum Warszawy o nazwie „Rzeczy warszawskie”. Można tam obejrzeć kilka tysięcy eksponatów. Są wśród nich oryginalne dzieła sztuki i rzeczy codzienne, z których każda posiada swoją historię. Bardzo chciałam zobaczyć z bliska wszystkie te rzeczy i posłuchać opowieści o nich. Można się zastanawiać, co takiego ciekawego jest w tych starych rzeczach? Dla niektórych zwiedzanie muzeum może wydawać się nudne, ale nic bardziej mylnego! Dla mnie wyprawa do muzeum była bardzo ekscytująca (Autorka 6, 2018).

Niekiedy wśród wyróżnionych prac znaleźć można takie, w których nadmiar informacji, będących parafrazą tekstów zamieszczonych w przewodnikach i na stronach internetowych, zastępuje dziecięcą swobodną wyobraźnię, 
kreującą rzeczywistość właśnie na dziecięcą miarę. Widać w tym kreację na lubianego przez wychowawców, rodziców i nauczycieli wzorowego ucznia, dla którego wiedza, a nie twórczość, chęć do nauki, a nie wyobraźnia stanowią o wartości utworu - analogicznie do wypracowań szkolnych. Widoczne są tu wpływy dorosłych perswadujących dzieciom, że podstawową wartością lektury jest sfera poznawcza, zgodnie z bałamutnym sloganem: „Czytaj, a będziesz dużo wiedział”, całkowicie zdezaktualizowanym w czasach powszechnego dostępu do tzw. nowych mediów, ale wciąż powtarzanym przez dorosłych, tłumaczących dzieciom, dlaczego warto sięgać po książki. Przykład z pracy uczennicy IV klasy szkoły podstawowej:

Wchodząc do środka przekonałam się, że wnętrze Łazienek nasycone jest dekoracjami malarskimi i rzeźbiarskimi. Stanisław August wyjaśnił, że za sprawą dwóch architektów: Dominika Merliniego pochodzącego z Włoch i Jana Chrystiana Kamsetzera urodzonego w Dreźnie, zmienił barokowy pawilon Łaźni w Pałac na Wyspie w stylu klasycystycznym. W dekoracji malarskiej centralnego salonu Pałacu na Wyspie odwołano się do historii biblijnego króla Salomona. Malowidła Marcello Bacciarellego przedstawiały Sen Salomona, Sąd Salomona, Naradę Salomona z królem Hiramem nad budową świątyni, Odwiedziny Królowej Saby, Poświęcenie świątyni Jerozolimskiej i Salomona czyniącego ofiarę bożyszczom na żądanie swoich oblubienic. Król zgromadził imponujący zbiór malarstwa, rzeźby, grafiki, europejskich i polskich artystów. Do najcenniejszych dzieł sztuki zaliczyć należy obrazy autorstwa Rembrandta van Rijn: Dziewczyna w ramie obrazu i Uczony przy pulpicie (Autorka 7, 2018).

Podobnie z pomnikami - owszem, pojawia się pomnik Małego Powstańca, ale brakuje typowo „dziecięcych” ciekawostek: usytuowanego na Gocławiu pomnika Kota Niezależnego Cyryla, rzeźby Złotej Kaczki przy Zamku Ostrogskich, pomnika psa na Polu Mokotowskim, pomnika Praskiej Kapeli Podwórkowej na Pradze (ciekawe postaci muzyków, świetnie zwizualizowane instrumenty: skrzypce, gitara, mandolina, akordeon, bęben). Może my, dorośli, nie potrafimy znaleźć w mieście miejsc, które byłyby ciekawe dla dzieci? Może sami pokazujemy im jedynie to, co tuzinkowe i banalne, co naszym zdaniem ikoniczne? Zaledwie jedno dziecko dostrzegło warszawskie atrakcje dziecięce: park linowy i Multimedialny Park Fontann, ale co z tego, skoro odnotowało ich istnienie jedynie lakoniczną wzmianką. Warszawski ogród zoologiczny, miejsce pielgrzymek rodzin i wycieczek szkolnych, też nie inspiruje. Zoo pojawiło się $\mathrm{w}$ jednej z prac, ale zaledwie wspomniane, bez choćby napomknięcia o jednej z największych atrakcji dla dzieci: pokazach karmienia zwierząt - pingwinów, fok, gibonów, nosorożców, hipopotamów, ryb... Nie ma 
też Muzeum dla Dzieci im. Janusza Korczaka, które działa od 2003 roku w ramach Państwowego Muzeum Etnograficznego. Nie ma Warszawskiego Domu Zagadek, mieszczącego się w sąsiedztwie Multimedialnego Parku Fontann. Nie ma Manufaktury Cukierków, gdzie dzieci mogą zobaczyć, jak powstają cukierki i lizaki w 80 smakach i 150 wzorach (niektóre z tych wzorów nawiązują do postaci z popularnych dziecięcych filmów). W niewymienionym w pracach Parku Trampolin Stacja Grawitacja - same atrakcje: dwunastometrowy najazd dla snowboardzistów, baseny wypełnione gąbkami i piłkami, dziesiątki trampolin i batuty przeznaczone do wykonywania skoków z akrobacjami. Pominięto zarówno miejsca znane, np. Centrum Nauki Kopernik (zaledwie parę lakonicznych wzmianek), jak i mniej popularne, a zaciekawiające (Centrum Pieniądza, gdzie można zobaczyć milion złotych w banknotach, zwiedzić skarbiec i trzymać w rękach sztabkę czystego złota; Muzeum Kolejnictwa, Muzeum Farmacji, Muzeum Techniki, Muzeum Pożarnictwa). Niedawno do tych atrakcji warszawskich dołączył Flyspot - najnowocześniejszy w Europie tunel aerodynamiczny, w którym dziecko może poczuć się Batmanem, Spider-Manem czy Piotrusiem Panem i zaznać przyjemności swobodnego unoszenia się w powietrzu. Żadne z tych miejsc nie zagościło na horyzoncie dziecięcych skojarzeń z Warszawą. Lista nieobecności „,rzeczy dziecięcych”, muzeów, pomników, obiektów zapewniających atrakcje i emocje, jest zastanawiająca. Zdaje się potwierdzać sformułowaną wyżej tezę, zgodnie z którą dziecięcy autorzy prac literackich dokonują autokreacji, starają się „dojrzeć”, sprostać „dorosłym” wymogom, które ich zdaniem obowiązują pisarza. Stąd duża dawka wiedzy książkowej, koncentracja uwagi na tym, co stworzony przez dorosłych świat uważa za godne wspomnienia, ważne i twórcze. Autorzy dosłownie „wyzbyli się tego, co dziecięce”, jakby parafrazując biblijne słowa apostoła Pawła (Biblia Tysiąclecia, 1 Kor 13, 11).

Powyższe refleksje prowadzą do dwóch wniosków. Pierwszy z nich dotyczy samej przestrzeni miasta, w której to, co zorientowane na młodych i najmłodszych jego mieszkańców i gości, przynależy do przestrzeni nieoczywistej, skrytej, a nie jawnej; do przestrzeni, którą trzeba rozpoznać, kierując się nieoczywistymi drogowskazami. Brakuje profesjonalnych przewodników i map, prezentujących przestrzenie miast $\mathrm{z}$ perspektywy zainteresowań i potrzeb emocjonalnych dzieci, brakuje stron internetowych, które mogłyby podpowiadać, w jaki sposób i czym miasta uwodzą małych mieszkańców i przybyszów. Ta nieoczywista, skrywana przestrzeń, nieobecna ani w dyskursie publicznym, ani w dydaktyce szkolnej, jest niedostępna dzieciom, bo nieznana im. Skazani na dorosłych pośredników dziecięcy autorzy wędrują więc „dorosłymi ścieżkami”, mijając to, co mogłoby je zachwycić. Od przeżycia zachwytu do wyrobienia 
trwałych związków z „małą ojczyzną”, krajem lat dziecinnych, towarzyszącym zawieszonej w bezczasie dorosłości, jest krok bardzo mały.

Wniosek drugi stanowi znacznie trudniejsze zadanie niż jedynie zmianę orientacji $\mathrm{w}$ procesie prezentowania przestrzeni miejskich dziecięcym mieszkańcom miast i rówieśnym im turystom. Inspirujące dziecięcą twórczość literacką konkursy są tym bardziej wartościowe, im skuteczniej potrafią wyzwolić w dzieciach autentyczną potrzebę aktywności pisarskiej, wyrastającej z ich doznań, przeżyć, spostrzeżeń i zainteresowań. Nawet bardzo atrakcyjne tematy, a takimi były np. Warszawa $w$ Twojej legendzie (2016) czy Rzecz o rzeczach warszawskich (2018), mogą zostać zneutralizowane przez adultyzujące dążenie dziecięcych autorek i autorów do sprostania wymogom twórczości „dorosłej”, „dojrzałej” i „mądrej”. W jaki sposób skłonić dzieci i nastolatki, by pisały tak, jak czują, pisały „sobą”, swoimi wyobrażeniami, marzeniami, pragnieniami, swoim językiem, swoimi emocjami; by przedstawiały miasto i jego przestrzeń tak, jak je widzą, a nie tak, by „wejść w buty” dorosłych? To jest praca rozłożona na wiele, wiele lat. Potrzebne byłyby warsztaty, zajęcia przygotowujące, rodzaj XIX-wiecznej „szkoły pisarzów”. Potrzebna byłaby przede wszystkim zmiana postaw społecznych, odejście od modelu wychowania opartego na opresji, prowadzącej do neutralizacji w młodym pokoleniu jego dziecięcych cech, na rzecz nowego sposobu kształtowania człowieka od najmłodszych lat, kształtowania prowadzącego do pogłębienia, a nie neutralizowania właściwych dzieciństwu przeżyć psychicznych i dopiero na tym fundamencie budowania dojrzałości emocjonalnej i intelektualnej. Sprzyja temu nowoczesna twórczość literacka zorientowana na dziecięcych odbiorców: książki polskie (m.in. Pawła Beręsewicza, Grzegorza Kasdepke, Joanny Olech, Anny Onichimowskiej, Małgorzaty Strzałkowskiej) i zagraniczne (np. Johna Boyne’a, Johna Greena, Davida Walliamsa), sprzyjało temu pisarstwo Anny Kamieńskiej, Janusza Korczaka, Joanny Kulmowej, Antoine’a de Saint-Exupéry'ego, Astrid Lindgren, Tove Jansson, utwory Jeana-Jacques'a Sempégo i Renégo Goscinnego. Jest zgubnym skutkiem oddziaływań szkoły, że dziecięcy autorzy łatwiej utożsamiają się z piszącym o Janku Muzykancie Sienkiewiczem, zasmuconym losem Anielki Prusem czy pochyloną nad dzieckiem Orzeszkową niż z pisarzem współczesnym. Dziecięcy twórcy nie czerpią inspiracji ze skierowanej do nich współczesnej literatury, z twórczości pisarzy, którzy chcą dorosnąć, ale nie do bycia nauczycielem czytających, lecz do bycia dzieckiem, jakby powtarzając za Korczakiem (1925): „[...] musimy się wspinać do ich uczuć. Wspinać, wyciągać, na palcach stawać, sięgać. Żeby nie urazić” (s. [5]).

Czy dziecięcy twórcy mogliby pójść jeszcze dalej i odrzucić wszelkie naśladownictwo? Zapewne tak, historia literatury dziecięcej i książki od dawna 
zna tego rodzaju przypadki - w wydanych przed czterdziestu laty dwóch antologiach: dziecięcych wierszy Leci jabłko w chmury (Wawiłow, Usenko, 1982) i nastoletnich wypowiedzi o charakterze dzienników intymnych Kartki z mojego pamiętnika (Tylicka, 1979) mieliśmy do czynienia $\mathrm{z}$ utworami zasadniczo wolnymi od naśladownictw. Antologia pierwsza zbierała teksty dzieci tak małych, że niepotrafiących jeszcze samodzielnie pisać i czytać - były to raczej zanotowane przez dorosłych fragmenty spontanicznych dziecięcych wypowiedzi, wzbudzające ich zainteresowanie tym właśnie, że oddawały sposób dziecięcego myślenia, swobodę traktowania języka jako tworzywa literatury, zaciekawiały odkrywczością metafor i niezwykle trudną do osiągnięcia w wieku dojrzałym spontaniczną erupcją poetyckiej wyobraźni. Antologia druga zbierała wyimki z dzienników intymnych nastolatków - wyimki te tym były ciekawsze, im więcej w nich było autentyzmu, szczerości i inwencji autorskiej, wykraczającej poza literackie schematy ${ }^{6}$. Konkurs ogłoszony przez instytucję edukacyjną i oceniany przez jury, w skład którego wchodzą dorośli, z natury rzeczy narzuca autorkom i autorom kostium wiedzowy, wtrącając twórców w schematy adultyzujące i kompromitując w ich oczach dziecięcy i młodzieńczy autentyzm.

Odpowiadając więc na pytanie początkowe: „Kim jest dziecko jako wpisany w teksty autor prac autodziecięcych, przesyłanych na konkursy literackie?” - trzeba powiedzieć, że dziecko-twórca jest współczesną realizacją dwóch wielkich toposów kultury europejskiej: puer-senex, „chłopca-starca”, i docta puella, „uczonej dziewczynki”.

\section{Bibliografia}

Autorka 1. (2016). Tajemnica Pomnika [praca nagrodzona w I edycji konkursu varsavianistycznego]. Archiwum Muzeum Warszawy.

Autorka 2. (2017). Zima $w$ Warszawie [praca nagrodzona w II edycji konkursu varsavianistycznego]. Archiwum Muzeum Warszawy.

Autorka 3. (2019). Kolory Warszawy [praca nagrodzona w IV edycji konkursu varsavianistycznego]. Archiwum Muzeum Warszawy.

Autorka 4. (2018). Tajemniczy imbryk [praca nagrodzona w III edycji konkursu varsavianistycznego]. Archiwum Muzeum Warszawy.

6 O problemie szczerości i autokreacji w memuarystyce pisał m.in. Paweł Rodak (2011) w książce Między zapisem a literaturą. Dziennik polskiego pisarza w XX wieku (Żeromski, Nałkowska, Dąbrowska, Gombrowicz, Herling-Grudziński). 
Autorka 5. (2018). Historia pewnego lustra [praca nagrodzona w III edycji konkursu varsavianistycznego]. Archiwum Muzeum Warszawy.

Autorka 6. (2018). Rzeczy warszawskie [praca nagrodzona w III edycji konkursu varsavianistycznego]. Archiwum Muzeum Warszawy.

Autorka 7. (2018). Królewski podarunek [praca nagrodzona w III edycji konkursu varsavianistycznego]. Archiwum Muzeum Warszawy.

Cieślikowski, J. (1974). Okolica dzieciństwa. W: Literatura i podkultura dziecięca (s. 158-182). Zakład Narodowy im. Ossolińskich.

Gloton, R., Clero, C. (1976). Twórcza aktywność dziecka (I. Wojnar, tłum. i wstęp). WSiP. (wyd. oryg. 1971).

Irzykowski, K. (1903). Pałuba. Sny Marii Dunin. Księgarnia Polska B. Połonieckiego, E. Wende i Spółka.

Jarzębińska, A., Chojnacka, A. (2018). „Karmienie się dzieckiem na żądanie” - doświadczenie parentyfikacji w relacjach uczestników internetowych forów dyskusyjnych. Dziecko Krzywdzone. Teoria, Badania, Praktyka, 17(2), 165-185.

Karpieszuk, W., Wojtczuk, M. (2018, 6 czerwca). Tęcza wróciła na pl. Zbawiciela z przesłaniem: chcemy równości małżeńskiej. Gazeta Wyborcza. Pobrane 22 września 2020 z: https://warszawa.wyborcza.pl/warszawa/7,54420,23503843,tecza-wraca-na-pl-zbawiciela-z-przeslaniem-chcemy-rownosci.html.

Kasia, K. (2019, 8 maja). Dlaczego właściwie tęcza profanowała Matkę Boską?. Newsweek. Pobrane 22 września $2020 \mathrm{z}$ : https://www.newsweek.pl/opinie/dlaczegowlasciwie-tecza-sprofanowala-matke-boska/l776yt8.

Korczak, J. (1925). Kiedy znów będę mały. Wydawnictwo J. Mortkowicza, Towarzystwo Artystyczne w Warszawie.

Kruze-Sikorska, H. (2006). Edukacja przez sztukę. O edukacyjnych wartościach artystycznej twórczości dziecka. WN UAM.

Kujawiński, J. (red.). (1990). Rozwijanie aktywności twórczej uczniów klas początkowych. Zarys metodyki. WSiP.

Mickiewicz, A. (1832). Dziady. Część III. W: Poezye Adama Mickiewicza. Tom czwarty (s. 14-209). A. Pinard.

Muzeum Warszawy. (2020). Muzeum Warszawy zaprasza uczniów szkót podstawowych i ponadpodstawowych do wzięcia udziału w konkursie literackim pt. Opowiem Ci o Warszawie. Regulamin konkursu literackiego. Pobrane 15 września 2020 z: https://muzeumwarszawy.pl/wp-content/uploads/2020/02/Regulamin-konkursliteracki-pt.-Opowiem-Ci-o-Warszawie.pdf.

Okopień-Sławińska, A. (1987). Relacje osobowe w literackiej komunikacji. W: H. Markiewicz (red.), Problemy teorii literatury. Seria II. Prace z lat 1965-1974 (s. 58-74). Zakład Narodowy im. Ossolińskich.

Popek, S. (red.). (1988). Aktywność twórcza dzieci i młodzieży. WSiP. 
Rodak, P. (2011). Między zapisem a literatura. Dziennik polskiego pisarza w XX wieku (Żeromski, Nałkowska, Dąbrowska, Gombrowicz, Herling-Grudziński). Wydawnictwa UW.

Semenowicz, H. (1973). Poetycka twórczość dziecka. Nasza Księgarnia.

Tylicka, B. (wyb. i oprac.). (1979). Kartki z mojego pamiętnika. Młodzieżowa Agencja Wydawnicza.

Wawiłow, D., Usenko, O. (oprac.). (1982). Leci jabłko w chmury. Wiersze dzieci dla dzieci i dorostych. Nasza Księgarnia.

wkk. (2013, 11 listopada). Lider narodowców o tęczy: spłonął symbol zarazy. Gazeta Wyborcza. Pobrane 22 września 2020 z: https://warszawa.wyborcza.pl/warszawa /1,54420,14933380,Lider_narodowcow_o_teczy_ssplonal_symbol_zarazy.html.

Wróblewski, M. (2018). Kulturowe badania dzieciństwa. Zarys problemu. Literatura Ludowa, 62(4-5), 52-60. https://doi.org/10.12775/LL.4-5.2018.006.

Uszyńska-Jamrot, J. (2007). Od twórczości potencjalnej do autokreacji w szkole. Wydawnictwo Uniwersyteckie Trans Humana.

Zborowski, J. (1986). Rozwijanie aktywności twórczej dzieci. WSiP. 